\title{
GLASSHOUSE LOCATING BASED ON SWARA-COPRAS APPROACH
}

\section{Ramtin HAGHNAZAR KOUCHAKSARAEI a , Sarfaraz HASHEMKHANI ZOLFANI ${ }^{\text {b,c,*, }}$ Mahmood GOLABCHI a}

${ }^{a}$ College of Fine Arts, School of Architecture University of Tehran, P.O. Box 14155-6458, Tehran, Iran

${ }^{b}$ Technology Foresight Group, Department of Management, Science and Technology, Amirkabir University of Technology (Tehran Polytechnic), P.O. Box 1585-4413, Tehran, Iran

${ }^{c}$ Futures Studies Research Institute, Amirkabir University of Technology (Tehran Polytechnic), P.O. Box 1585-4413, Tehran, Iran

Received 1 March 2013; accepted 20 December 2013

\begin{abstract}
Glasshouse is a kind of greenhouse that is larger than prevalent greenhouses. Glasshouses may have wide various applications and totally, is more applicable than greenhouse. One important point about glasshouse that should be considered is selecting a good location. Besides, finding a suitable location for this purpose is so hard because establishing a glasshouse needs a large area. Financial justification which is a major issue in glasshouse Investments highlights the importance of its locating. This research is based on strategic property management perspectives and its results can be used to properly locate an economically justifiable glasshouse in both governmental and private levels. There are some other important criteria affects on this issue. This research aimed at presenting new hybrid framework for glasshouse locating based on two MCDM methods. SWARA and COPRAS are applied in this research for glasshouse locating. This methodology for the first time is applied in a research. SWARA is applied for evaluating criteria and COPRAS is applied for evaluating alternatives. For illustrating the research methodology, a case study in Tehran, Iran is presented in the research. This research can be useful as a framework for this aim and also has the advantage to apply in other research areas.
\end{abstract}

KEYWORDS: Glasshouse; Locating; SWARA; COPRAS; Multi Criteria Decision Making (MCDM)

\section{INTRODUCTION}

The most important human's ability which differentiates him from other creatures is decision making. Decision making is a very old science maybe as old as human being. In addition, today it is an important part of management science. Decision making can be regarded as a mental process resulting in the selection of a course of action among several alternative scenarios. Every decision making process produces a final choice (Reason 1990). The output can be an action or an opinion of choice.

There is a kind of decision making which called 'Location decision'. Location decision deals with problems whose information is geographical (Farahani et al. 2010), and it also named 'Location science'. Different types of maps are used in this kind of decision making. Maps introduce various data such as economic information, seismic maps,

\footnotetext{
* Corresponding author. E-mail: sa.hashemkhani@gmail.com
}

wind direction, transportation, etc. These materials define the criteria of the decision. Criteria for this paper will be introduced in next section.

Location science is started by Alfred Weber's book (Weber, Friedrich 1929), however quite a lot of comprehensive books have been written in the last 4 decades. There is a considerable body of literature about location science (for instance see, Church, Murray 2009; Daskin 1995; Francis et al. 1992; Handler, Mirchandani 1979; Love et al. 1988; Mirchandani, Francis 1990; Nickel, Puerto 2005).

A greenhouse is a building which constructed with light scaffold, because it has to be covered by transparent or translucent skin for maximum light transmission and heat retention. They are designed to prepare the artificial suitable situation for plants growing and save plants from different weather conditions (Freeman 1998; Zhang 
Table 1. Greenhouse guideline

\begin{tabular}{|c|c|c|}
\hline $\begin{array}{l}\text { Greenhouse } \\
\text { for use by }\end{array}$ & Function of greenhouse operations & Greenhouse design considerations \\
\hline High school & $\begin{array}{l}\text { Growing and/or maintaining small number } \\
\text { of plant specimens for observation. }\end{array}$ & $\begin{array}{l}\text { Space-10 sq.ft. per student enrolled in course. Requires con- } \\
\text { sistent, day-to-day control of environment. }\end{array}$ \\
\hline $\begin{array}{l}\text { Vocational } \\
\text { school }\end{array}$ & $\begin{array}{l}\text { Providing basic experience in commercial } \\
\text { crop production. }\end{array}$ & $\begin{array}{l}\text { Space- } 20 \text { sq.ft. per student enrolled in course. Greenhouse } \\
\text { should be small-scale edition of commercial operation with } \\
\text { three separate temperature zones: } 50-55^{\circ} \text { min., } 60^{\circ} \text { min., } \\
\& 65+^{\circ} \text { min. }\end{array}$ \\
\hline $\begin{array}{l}\text { Liberal arts } \\
\text { college, } \\
\text { university }\end{array}$ & $\begin{array}{l}\text { Growing and/or maintaining plant speci- } \\
\text { mens. Simple research projects involving } \\
\text { small number of plants. }\end{array}$ & $\begin{array}{l}\text { Space-10 sq.ft. per student using dept. Often greenhouse is } \\
\text { art of Science Building complex and must conform to other } \\
\text { architecture or site. Many configurations possible. }\end{array}$ \\
\hline $\begin{array}{l}\text { Agricultural } \\
\text { colleges }\end{array}$ & $\begin{array}{l}\text { Simulating commercial production of plant } \\
\text { materials. Propagating and finishing zones. } \\
\text { One or more crops, such as cut flowers, pot } \\
\text { plants, vegetables, ornamentals, etc. }\end{array}$ & $\begin{array}{l}\text { Space-100+ sq.ft. per student in dept. Layout, facilities, } \\
\text { equipment, and controls should be designed or horticultural } \\
\text { applications and equal to those used by commercial grow- } \\
\text { ers. }\end{array}$ \\
\hline $\begin{array}{l}\text { Scientific re- } \\
\text { search }\end{array}$ & $\begin{array}{l}\text { Complex research objects involving numer- } \\
\text { ous plants, multiple compartments for sepa- } \\
\text { rate climates, precise data recording. May } \\
\text { require separate cluster of working green- } \\
\text { houses for major research projects. }\end{array}$ & $\begin{array}{l}\text { Space-Varies from } 250 \text { sq.ft. up per growth chamber or com- } \\
\text { partment, depending on type of research. }\end{array}$ \\
\hline $\begin{array}{l}\text { Public } \\
\text { conservatory }\end{array}$ & $\begin{array}{l}\text { Display of plant collections. Usually pro- } \\
\text { vides three climates-tropic, temperate, arid. } \\
\text { May require separate cluster of working } \\
\text { greenhouses for plant production. Munici- } \\
\text { pal conservatories often grow plant materi- } \\
\text { als for all civic planted areas. }\end{array}$ & $\begin{array}{l}\text { Space- } 1.5 \text { acres per million population. Provide } 40,000 \text { sq. ft } \\
\text { working greenhouses to } 20,000 \text { sqft display area. Display } \\
\text { buildings re enhanced by acrylic glazing, design-oriented } \\
\text { structural systems. Criteria for working greenhouses same } \\
\text { as for commercial. }\end{array}$ \\
\hline $\begin{array}{l}\text { Commercial } \\
\text { growing } \\
\text { operation }\end{array}$ & $\begin{array}{l}\text { Actual production of plant materials. May } \\
\text { include all stages from propagating to fin- } \\
\text { ishing of single or multiple crops. }\end{array}$ & $\begin{array}{l}\text { Space- } 40,000 \text { sq.ft. min for profit. Glaze with glass, fiber } \\
\text { glass, combination, use sloping or curved roof profile. Pro- } \\
\text { vide } 1,000 \text { sq.ft. service area for } 6,000 \text { sq.ft. growing area. } \\
\text { Maximum environmental control justified on basis of in- } \\
\text { creased profitability. Single or multiple units, compartmen- } \\
\text { talized or open ridge and furrow. }\end{array}$ \\
\hline $\begin{array}{l}\text { Hobby } \\
\text { gardening }\end{array}$ & $\begin{array}{l}\text { Growing and/or maintaining small plant } \\
\text { collections, forcing bulbs, rooting seeding, } \\
\text { etc. }\end{array}$ & $\begin{array}{l}\text { Space-100 sq.ft. min. Small prefabricated bldg. with envi- } \\
\text { ronment package provides neat-appearing, horticultural } \\
\text { adequate unit. }\end{array}$ \\
\hline
\end{tabular}

Source: De Chiara and Callender (1990).

2003; Hixon 2009). A greenhouse is a building in which plants are grown. These buildings range in size from small sheds to huge structures. These structures are designed and constructed in different sizes and types for various usages (Marshal 2006). Greenhouses prepare artificial environment for growing the plants. In addition, greenhouses gather different plants from different climates in a single place. Also it is used to produce more plants with more quality.

Deferent types of greenhouse for various usages have been constructed around the world and a brief description is presented in the following. Altered purposes of greenhouses are mentioned in Table 1.

Greenhouse which is designed in the present project considers different classes of users. This building is designed for scientific researches use, public conservatory and commercial growing operation. Therefore, its area should be approximately $50,000 \mathrm{~m}^{2}$. Obviously, enormous cost of this building dictates that designers should pay more atten- tion to each step of the design process. This paper investigates a section in preliminary design part (locating) to find the best location for the project.

Large greenhouses which use to display different types of plants is called glasshouse. This research focuses on this kind of greenhouse. There are not so many glasshouses in the world and also there is not any greenhouse in this scale in Iran. Recently, importance of glasshouses in Iran has increased. Building the glasshouses requires the large areas and for this purpose, this research aimed at present new frameworks for selecting the best place to establish it.

Many different types of buildings and facilities have to be established in developing countries. Cultural and economical desires will be changed during the developing period and new buildings can satisfy new needs. Therefore, construction of these building is necessary.

Locating of a great glasshouse is the topic of this investigation, because it offers some advantages to its host city. Tehran as a metropolis needs 
more tourist attraction and monumental buildings. In cultural point of view, Tehran is a poor city and it doesn't have sufficient museum, exhibition, galleries and greenhouse. This building can satisfy some of these deficiencies.

One of the key strategic planning tools for institutions is property management. Many facilities have their critical importance in urban and national management. In addition, glasshouses are significant in Iran because of different aspects. Establishing a glasshouse has financial justifications for investors in Iran in both governmental and private models. Due to population growth of Iran more food is needed. Therefore, it's important to manage food industry in country. Another important issue in this subject is quality of food. The food industry isn't still up to date and advanced. Selecting the best place for establishing a glasshouse can increase its financial justifications and decrease strategic risk for investors. The results of this research can justify its importance. There are three stages in development of the projects in typical real states: the first is planning stage, the second is final planning stage and the last one is project management stage (Pellicer, Victory 2006). This research can be considered as a section in first stage.

In this research two MCDM methods including SWARA and COPRAS are applied for glasshouse locating. SWARA will use for evaluating and cal-

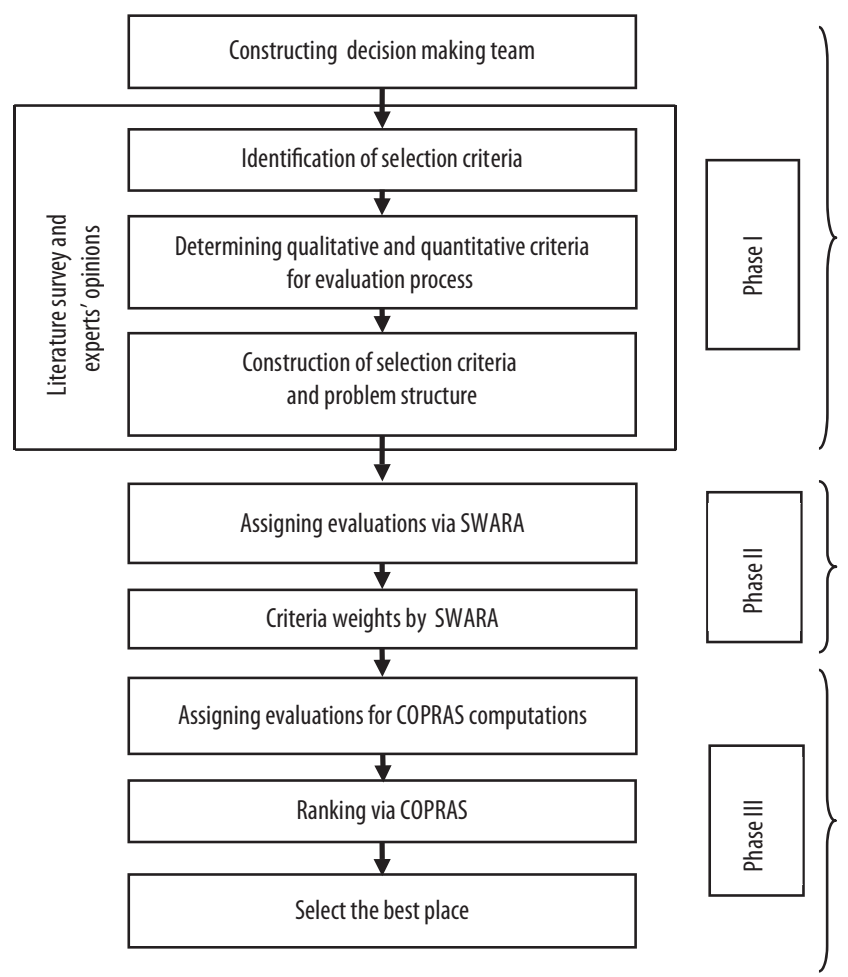

Fig. 1. The evaluation procedure of research culating weights and relative importance of each criterion and COPRAS will apply for evaluating alternatives that are selected in Tehran, Iran. The process of this research is shown in Figure 1.

\section{IDENTIFICATION OF NECESSARY CRITERIA FOR GLASSHOUSE LOCATING}

The main aim of this research is finding the best location for glasshouse. Desirable location is chosen by following criteria. These criteria are results of the literature review and they are weighted proper to the function and other properties of project.

The main important point in investment is selecting the best and right place (Guneri et al. 2009). The first point should be considered to design greenhouses is to choose the suitable site (location), (Jaafarnia, Homaei 2009; Rezaeiniya et al. 2012, 2014). Designers have to consider a number of factors in greenhouse locating: heating supply, greenhouse expansion plans, access to electricity, access to specialized labor, access to fuel (Jaafarnia, Homaei 2009; Rezaeiniya et al. 2012, 2014). Greenhouse is a place which covered by transparent or translucent materials and its temperature, light, humidity and other environmental factors should be managed (Hasandokht 2005; Rezaeiniya et al. 2012, 2014). Land costs, construct costs, accessibility of raw materials (Hasandokht 2005; Rezaeiniya et al. 2012, 2014), use of appropriate soil, labor costs, access to proper transportation (Hasandokht 2005; Jaafarnia, Homaei 2009; Rezaeiniya et al. 2012, 2014), land topography, proximity to market, access to adequate water (Jaafarnia, Homaei 2009; Mollahoseini, Seylsepur 2008; Rezaeiniya et al. 2012, 2014), are a part of the important criteria for greenhouse locating.

There are some other criteria which are mentioned by architectural standard references: access to fresh air, admitting the greatest possible amount of available light, should not be shaded by buildings or trees, considering the wind direction in warm and cold weather, accessibility by public transportation, and paying attention to aesthetic potential of site (De Chiara, Callender 1990). The house must be on a site that takes advantage of wind breaks but is not shaded by trees or neighboring structures, also has good water drainage and run-off, and permits easy access during winter for fuel deliveries and general work, and a good water supply must be available for efficient operation (Sheldrake 1992).

As mentioned before, study about the effect of environmental conditions is one of the 
Table 2. Criteria and sub-criteria classification and description

\begin{tabular}{|c|c|c|c|c|}
\hline Criteria & Sub-criteria & & & Description \\
\hline \multirow{4}{*}{$\begin{array}{l}\text { Physical con- } \\
\text { dition and } \\
\text { potential }\end{array}$} & $\begin{array}{l}\text { Expansion possibil- } \\
\text { ity }\end{array}$ & $\mathrm{C}_{1-1}$ & $\operatorname{Max}$ & $\begin{array}{l}\text { Larger site and better infrastructure have better possibility } \\
\text { for expansion }\end{array}$ \\
\hline & $\begin{array}{l}\text { Infrastructure ad- } \\
\text { equacy }\end{array}$ & $\mathrm{C}_{1-2}$ & $\operatorname{Max}$ & Infrastructure should be proper to the large greenhouse \\
\hline & $\begin{array}{l}\text { Aesthetic potential } \\
\text { of site }\end{array}$ & $\mathrm{C}_{1-3}$ & $\operatorname{Max}$ & $\begin{array}{l}\text { Site should be capable to show the building and should be } \\
\text { located in the beautiful landscape }\end{array}$ \\
\hline & $\begin{array}{l}\text { Regional commercial } \\
\text { situation }\end{array}$ & $\mathrm{C}_{1-4}$ & $\operatorname{Max}$ & $\begin{array}{l}\text { People who live in the close areas should be rich enough to } \\
\text { buy flower and visit the exhibitions }\end{array}$ \\
\hline \multirow[t]{7}{*}{ Environment } & Proper soil & $\mathrm{C}_{2-1}$ & $\operatorname{Max}$ & $\begin{array}{l}\text { Greenhouses need to use proper soil to grow the flowers and } \\
\text { trees and these soil have to be changed regularly }\end{array}$ \\
\hline & Proper water & $\mathrm{C}_{2-2}$ & $\operatorname{Max}$ & Proper source of water is needed for growing the plants \\
\hline & Fresh air & $\mathrm{C}_{2-3}$ & $\operatorname{Max}$ & Clean and fresh air increase the glasshouse's performance \\
\hline & Air pollution & $\mathrm{C}_{2-4}$ & Min & Polluted air damages the plants \\
\hline & Wind breaks & $\mathrm{C}_{2-5}$ & $\operatorname{Max}$ & $\begin{array}{l}\text { High-speed wind during cold season makes the glasshouse } \\
\text { cold and trees and other wind breakers decrease its negative } \\
\text { effect }\end{array}$ \\
\hline & $\begin{array}{l}\text { Possibility for } \\
\text { natural ventilation }\end{array}$ & $\mathrm{C}_{2-6}$ & Max & $\begin{array}{l}\text { Middle-speed wind which moves fresh air to the site can be } \\
\text { used for natural ventilation }\end{array}$ \\
\hline & $\begin{array}{l}\text { Shading by sur- } \\
\text { rounding objects }\end{array}$ & $\mathrm{C}_{2-7}$ & Min & Glasshouse should get enough daylight during days \\
\hline \multirow[t]{3}{*}{ Accessibility } & $\begin{array}{l}\text { Public } \\
\text { transportation }\end{array}$ & $\mathrm{C}_{3-1}$ & $\operatorname{Max}$ & $\begin{array}{l}\text { Site should be connected to highways and people should } \\
\text { reach it easily }\end{array}$ \\
\hline & $\begin{array}{l}\text { Private } \\
\text { transportation }\end{array}$ & $\mathrm{C}_{3-2}$ & $\operatorname{Max}$ & \\
\hline & $\begin{array}{l}\text { Heavy vehicle, Fuel, } \\
\text { etc. }\end{array}$ & $\mathrm{C}_{3-3}$ & $\operatorname{Max}$ & $\begin{array}{l}\text { Heavy vehicle cannot move easily through the city and the } \\
\text { site should be connected to highways }\end{array}$ \\
\hline
\end{tabular}

most important classes of criteria (Jones 1966; Kronenberg, Van de Hulst 1984; Nisbet, Chee 1977). Ventilation and natural ventilation are the most complex part of greenhouse designing and natural ventilation depends on location and site analysis. Effect of wind direction and speed were studied in many articles (Hooff, Blocken 2010; Horan, Finn 2008). Calculation the effect of natural ventilation was investigated in some papers (Chu et al. 2011). Due to international sanction against Iran, economical situation and rate of inflation in recent years in this country, making an appropriate decision is so hard in this country. Rate of inflation (October $2012-$ October 2013) in Iran didn't decrease less than $32 \%$ (Trading Economic 2013). Hence, defining quantitative criteria don't seem reasonable. The priority is to have a glasshouse in Tehran (Iran) and financial issue isn't major concern about establishing that.

Table 2 represent final identified criteria.

\section{METHODOLOGY}

The SWARA-COPRAS methodology is presented the first time by Hashemkhani Zolfani and Zavadskas (2013). This new hybrid model can be more helpful in decision and policy making. This model is useful in top level of decision making and authors believe that this model is completely suitable for this type of research and in this level.

\subsection{Step-wise weight assessment ratio analysis (SWARA) method}

Weight assessment is an important issue in many MADM problems. Some famous weight assessment approaches in the literature including analytic hierarchy process (AHP) (Saaty 1980; Gudiene et al. 2014), analytic network process (ANP) (Saaty, Vargas 2001), Entropy (Shannon 1948; Sušinskas et al. 2011; Kersuliene, Turskis 2011), FARE (Ginevicius 2011), SWARA (Keršulienè et al. 2010), etc. Among these methods, SWARA method is one of the brand-new ones. 


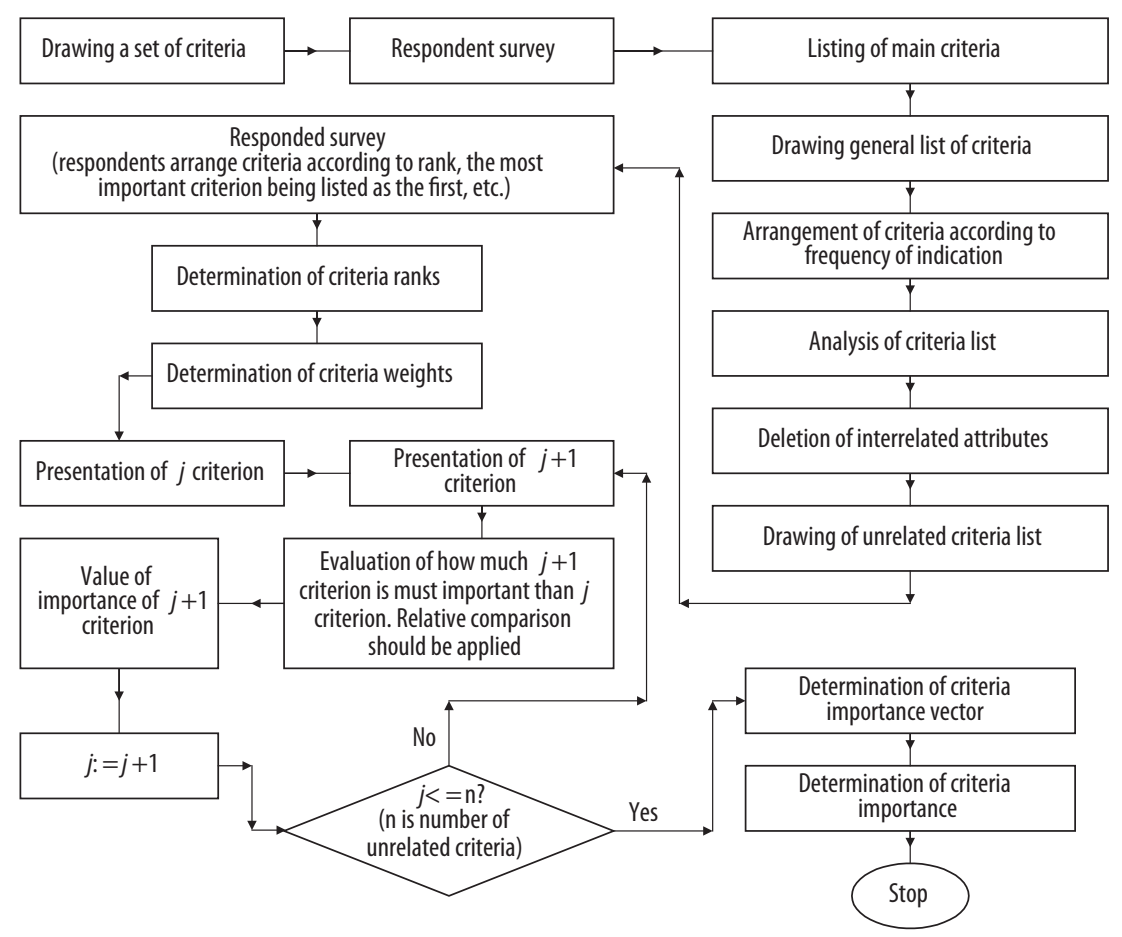

Fig. 2. Determining of the criteria weights based on (Kersuliene, Turskis 2011)

In this method, expert has an important role on evaluations and calculating weights. Also, each expert has chosen the importance of each criterion. Next, each expert ranks all the criteria from the first to the last one. An expert uses his or her own implicit knowledge, information and experiences. Based on this method, the most significant criterion is given rank 1 , and the least significant criterion is given rank last. The overall ranks to the group of experts are determined according to the mediocre value of ranks (Kersuliene, Turskis 2011).

The ability to estimate experts' opinion about importance ratio of the criteria in the process of their weights determination is the main element of this method (Keršulienè et al. 2010). Moreover, this method is helpful for coordinating and gathering data from experts. Furthermore, SWARA method is uncomplicated and experts can easily work together. The main advantage of this method in decision making is that in some problems priorities are defined based on policies of companies or countries and there aren't any needs for evaluation to rank criteria.

In other methods like AHP or ANP, our model is created based on criteria and experts' evaluations will affect priorities and ranks. So, SWARA can be useful for some issues that priorities are known former according to situations and finally SWARA proposed for applying in certain environ- ment of decision making. The all developments of decision making models based on SWARA method up to now are listed below: Keršuliene et al. (2010) in selection of rational dispute resolution method, Kersuliene and Turskis (2011) for architect selection, Hashemkhani Zolfani et al. (2013a) in design of products, Aghdaie et al. (2013a) in machine tool selection, Hashemkhani Zolfani et al. (2013b) in selecting the optimal alternative of mechanical longitudinal ventilation of tunnel pollutants, Hashemkhani Zolfani et al. (2013c) in investigating on the success factors of online games based on explorer, Hashemkhani et al. (2013d) in decision making on business issues with foresight perspective and Hashemkhani Zolfani and Zavadskas (2013) in sustainable Development of Rural Areas' Building Structures Based on Local Climate.

The procedure for the criteria weights determination is presented in Figure 2.

\subsection{COPRAS (Complex Proportional ASsessment) method (Zavadskas et al. 1994; Zavadskas, Kaklauskas 1996)}

In order to evaluate the overall efficiency of an alternative, it is essential to identify most important criteria, to evaluate alternatives and assess information with respect to these criteria; develop methods for evaluating the criteria to meet the DMs' needs. Decision analysis is concerned with the situation in which a DM has to choose among several 
alternatives by considering a particular set of, usually conflicting criteria. For this reason Complex proportional assessment (COPRAS) method which was developed by Zavadskas and Kaklauskas (1996) can be applied. In real situations, the most of the criterion for evaluating alternatives deals with vague feature, and values of criteria cannot be expressed with exact numbers.

The recent developments of decision making models based on COPRAS method are listed below:

Hashemkhani Zolfani et al. (2012) in supplier selection, Chandra Das et al. (2012) A framework to measure relative performance of Indian technical institutions, Saho et al. (2012) establishing green supplier appraisement platform, Barysienè (2012) evaluation of container terminal technologies applying, Aghdaie et al. (2012) prioritizing projects of municipality, Ranjan Maity et al. (2012) Cutting tool material selection, Staniunas et al. (2013) Ecological-economical assessment of multi-dwelling houses modernization, Mulliner et al. (2013) assessment of sustainable housing affordability, Tamosaitiene and Gaudutis (2013) assessment of structural systems used for high-rise buildings, Nguyen et al. (2014) machine tool selection and Aghdaie et al. (2013b) market segment evaluation and selection.

The procedure of applying the COPRAS method consists in the following steps:

1. Selecting the set of the most important criteria, describing the alternatives.

2. Constructing the decision-making matrix $X$,

$$
X=\left[\begin{array}{cccc}
x_{11} & x_{12} & \ldots & x_{1 m} \\
x_{21} & x_{22} & \ldots & x_{2 m} \\
\vdots & \vdots & \ddots & \vdots \\
x_{n 1} & x_{n 2} & \ldots & x_{n m}
\end{array}\right] ; i=\overline{1, n} \text { and } j=\overline{1, m},(1)
$$

where: attribute $j$ is in the alternative $i$ of a solution; $m$ is the number of attributes; $n$ is the number of the alternatives compared:

3. Determining significances of the criteria $q_{i}$.

4. Normalizing the decision-making matrix $\bar{X}$. The normalized values of this matrix are calculated as:

$$
\bar{x}_{i j}=\frac{x_{i j}}{\sum_{j=1}^{n} x_{i j}} ; i=\overline{1, n} \text { and } j=\overline{1, m} \text {. }
$$

After this step we have normalized decision making matrix:

$$
\bar{X}=\left[\begin{array}{cccc}
\bar{x}_{11} & \bar{x}_{12} & \ldots & \bar{x}_{1 m} \\
\bar{x}_{12} & \bar{x}_{12} & \ldots & \bar{x}_{2 m} \\
\ldots & \ldots & \ddots & \ldots \\
\bar{x}_{n 1} & \bar{x}_{n 1} & \ldots & \bar{x}_{n m}
\end{array}\right] .
$$

5. Calculating the weighted normalized decision matrix $\hat{X}$. The weighted normalized values $\hat{X}_{i j}$ are calculated as follows:

$$
\hat{x}_{i j}=\bar{x}_{i j} \cdot q_{j} ; i=\overline{1, n} \text { and } j=\overline{1, m},
$$

where: $q_{j}$ is the significance of the $i$-th criterion. Then, the normalized decision-making matrix is:

$$
\hat{X}=\left[\begin{array}{cccc}
\hat{x}_{11} & \hat{x}_{11} & \ldots & \hat{x}_{11} \\
\hat{x}_{11} & \hat{x}_{11} & \ldots & \hat{x}_{11} \\
\vdots & \vdots & \ddots & \vdots \\
\hat{x}_{11} & \hat{x}_{11} & \ldots & \hat{x}_{11}
\end{array}\right] ; i=\overline{1, n} \text { and } j=\overline{1, m} .
$$

6. Calculating the sums $P_{i}$ of criterion values, whose larger values are more preferable:

$$
P_{i}=\sum_{j=1}^{k} \hat{x}_{i j} .
$$

7. Calculating the sums $R_{i}$ of criterion values, whose smaller values are more preferable:

$$
R_{i}=\sum_{j=k+1}^{m} \hat{x}_{j}
$$

In formula (7), $(m-k)$ is the number of criteria which must be minimized.

8. Determining the minimal value of $R_{i}$ as follows:

$$
R_{\min }=\min _{i} R_{i} ; i=\overline{1, n} .
$$

9. Calculating the relative significance of each alternatively $Q_{i}$ the expression:

$$
Q_{i}=P_{i}+\frac{R_{\min } \sum_{i=1}^{n} R_{i}}{R_{i} \sum_{i=1}^{n} \frac{R_{\min }}{R_{i}}} .
$$

10. Determining the optimally criterion by $K$ the formula:

$$
K=\max _{i} Q_{i} ; i=\overline{1, n} .
$$

11. Determining the priority order of the alternatives.

12. Calculating the utility degree of each alternative by the formula:

$$
N_{j}=\frac{Q_{i}}{Q_{\max }} \times 100 \% .
$$

where: $Q_{j}$ and $Q_{\max }$ are the significances of the alternatives obtained from Eq. (9). 


\section{CASE STUDIES}

Four alternatives were considered as case studies for location in preliminary design. These cases have various advantages and disadvantages which will be investigated in decision making parts. All four alternatives are located in or around Tehran (capital of Iran) and this metropolis has unique and especial specifications which play critical role in criteria weights. Therefore, this point makes weights different from similar situations.

'Pardisan Park' $\left(\mathrm{A}_{1}\right)$ and 'Bustan-e-Mellat Park' $\left(\mathrm{A}_{2}\right)$ are first and second cases which are located in the city. 'Botanic Garden of University of Tehran' $\left(\mathrm{A}_{3}\right)$ and 'Chitgar Park' $\left(\mathrm{A}_{4}\right)$ are other cases which located around the city. Both $\mathrm{A}_{1}$ and $\mathrm{A}_{2}$ alternatives are the huge park with more than $100 \mathrm{~s}$ hectometer area. They are planned for iconic cultural-scientific buildings in urban plan of Tehran and proper infrastructure which were constructed in these sites. Third and fourth alternatives are greatest botanic garden in Iran which has the capability of mentioned glasshouse. All four alternatives are governmental because the investigator of the project is Tehran municipality. The four cases are shown in Figure 3.

SWARA like other similar methods (AHP and ANP) is based on the expert's ideas, but experts can be participated easily in this method. Experts are participated in COPRAS method too.

Information about experts is shown in Table 3. Ten experts of game designing participated in this research. They have worked on web designing, graphics, marketing instructing and software. All of the experts were interested in this topic and had some experience in this issue.
Table 3. Background information of experts

\begin{tabular}{lll}
\hline Category & Classification & No. \\
\hline Working & Civil engineering & 3 \\
background & Architecture & 2 \\
& Agricultural engineering & 1 \\
& Mechanical engineering & 1 \\
& Electrical engineering & 1 \\
Education & Economic & 2 \\
Level & Bachelor & 0 \\
& Master & 7 \\
Sex & PhD & 3 \\
& Male & 7 \\
\hline
\end{tabular}

Presenting a framework and evaluating the needs from several perspectives, the researcher proposed these six areas and fields in this research. Then the experts stated their opinions on identifying relative importance of each criterion to estimate the values of each criterion and finally, experts evaluated alternatives. The main point in this part is experts consider all of criteria qualitative. The model didn't consider cost of establishing the glasshouse because this project is national and selected places are in ownership of Tehran municipality. In addition, quality is more important against cost issue. An issue should be considered that there isn't an ideal alternative (place) and alternatives didn't comparison to ideal alternative. Relative advantages of each alternative are considerable. The concentrate of experts is on strategic perspective. This research is just concentrate on strategic perspective on glasshouse locating and management. To put it
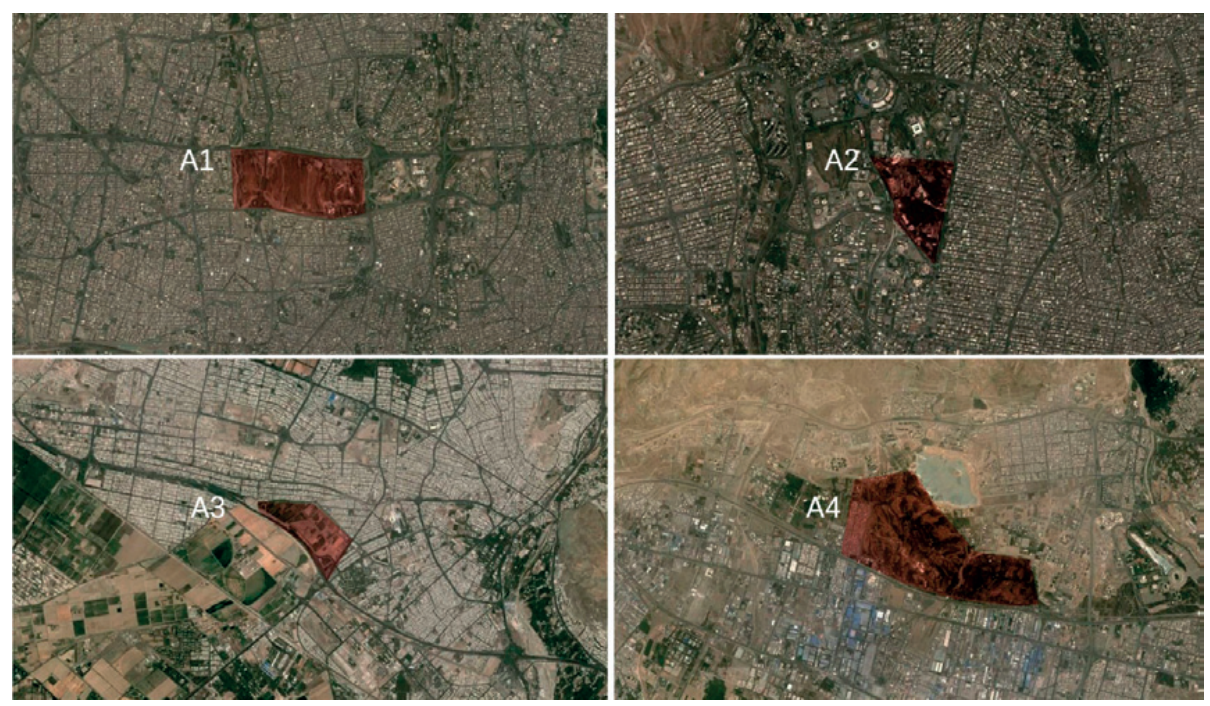

Fig. 3. The location of cases in urban space 
Table 4. Final results of SWARA method in weighting criteria

\begin{tabular}{lllll}
\hline Criterion & $\begin{array}{l}\text { Comparative importance of } \\
\text { average value } \\
S_{j}\end{array}$ & $\begin{array}{c}\text { Coefficient } \\
k_{j}=s_{j}+1\end{array}$ & $\begin{array}{l}\text { Recalculated weight } \\
w_{j}=\frac{x_{j-1}}{k_{j}}\end{array}$ & $\begin{array}{l}\text { Weight } \\
q_{j}=\frac{w_{j}}{\sum w j}\end{array}$ \\
\hline $\mathrm{X}_{2}$ & 1 & 1 & 0.41 \\
$\mathrm{X}_{1}$ & 0.23 & 1.23 & 0.813 & 0.334 \\
$\mathrm{X}_{3}$ & 0.295 & 1.295 & 0.627 & 0.256
\end{tabular}

* At the first level of decision hierarchy, three criteria are located. Environment was selected as the most important criterion.

Table 5. Final results of SWARA method in weighting physical condition and potential criteria

\begin{tabular}{lllll}
\hline Criterion & $\begin{array}{l}\text { Comparative importance of } \\
\text { average value } \\
S_{j}\end{array}$ & $\begin{array}{l}\text { Coefficient } \\
k_{j}=s_{j}+1\end{array}$ & $\begin{array}{l}\text { Recalculated weight } \\
w_{j}=\frac{x_{j-1}}{k_{j}}\end{array}$ & $\begin{array}{l}\text { Weight } \\
q_{j}=\frac{w_{j}}{\sum w j}\end{array}$ \\
\hline $\mathrm{X}_{1-2}$ & & 1 & 1 & 0.318 \\
$\mathrm{X}_{1-3}$ & 0.185 & 1.185 & 0.843 & 0.268 \\
$\mathrm{X}_{1-4}$ & 0.17 & 1.17 & 0.720 & 0.229 \\
$\mathrm{X}_{1-1}$ & 0.235 & 1.235 & 0.582 & 0.185
\end{tabular}

* Infrastructure adequacy was selected as the most important sub-criterion in physical condition and potential criteria.

Table 6. Final results of SWARA method in weighting criteria of environment

\begin{tabular}{lllll}
\hline Criterion & $\begin{array}{l}\text { Comparative importance of } \\
\text { average value } \\
S_{j}\end{array}$ & $\begin{array}{l}\text { Coefficient } \\
k_{j}=s_{j}+1\end{array}$ & $\begin{array}{l}\text { Recalculated weight } \\
w_{j}=\frac{x_{j-1}}{k_{j}}\end{array}$ & $\begin{array}{l}\text { Weight } \\
q_{j}=\frac{w_{j}}{\sum w j}\end{array}$ \\
\hline $\mathrm{X}_{2-2}$ & & 1 & 1 & 0.197 \\
$\mathrm{X}_{2-1}$ & 0.16 & 1.16 & 0.862 & 0.170 \\
$\mathrm{X}_{2-4}$ & 0.2 & 1.2 & 0.718 & 0.140 \\
$\mathrm{X}_{2-3}$ & 0 & 1 & 0.718 & 0.140 \\
$\mathrm{X}_{2-6}$ & 0 & 1 & 0.718 & 0.140 \\
$\mathrm{X}_{2-5}$ & 0.22 & 1.22 & 0.588 & 0.116 \\
$\mathrm{X}_{2-7}$ & 0.195 & 1.195 & 0.492 & 0.097
\end{tabular}

* Proper water was selected as the most important sub-criterion in environment criteria.

Table 7. Final results of SWARA method in weighting criteria of accessibility

\begin{tabular}{lllll}
\hline Criterion & $\begin{array}{l}\text { Comparative importance of } \\
\text { average value } S_{j}\end{array}$ & $\begin{array}{l}\text { Coefficient } \\
k_{j}=s_{j}+1\end{array}$ & $\begin{array}{l}\text { Recalculated weight } \\
w_{j}=\frac{x_{j-1}}{k_{j}}\end{array}$ & $\begin{array}{l}\text { Weight } \\
q_{j}=\frac{w_{j}}{\sum w j}\end{array}$ \\
\hline $\mathrm{X}_{3-1}$ & 1 & 1 & 0.409 \\
$\mathrm{X}_{3-2}$ & 0.285 & 1.285 & 0.778 & 0.318 \\
$\mathrm{X}_{3-3}$ & 0.165 & 1.165 & 0.667 & 0.273 \\
\hline
\end{tabular}

* Public transportation was selected as the most important sub-criterion in accessibility criteria.

* $S_{j}$ is calculated based on average of expert's ideas. The information gained privately from each expert and the scale is based multiples of five percent. 
Table 8. Initial decision-making matrix with values of the attributes describing the compared alternatives (COPRAS)

\begin{tabular}{|c|c|c|c|c|c|c|c|c|c|c|c|c|c|c|}
\hline \multirow[t]{3}{*}{ Opt } & \multicolumn{4}{|l|}{$\mathrm{C} 1$} & \multicolumn{7}{|l|}{$\mathrm{C} 2$} & \multicolumn{3}{|l|}{ C3 } \\
\hline & $\mathrm{C}_{1-1}$ & $\mathrm{C}_{1-2}$ & $\mathrm{C}_{1-3}$ & $\mathrm{C}_{1-4}$ & $\mathrm{C}_{2-1}$ & $\mathrm{C}_{2-2}$ & $\mathrm{C}_{2-3}$ & $\mathrm{C}_{2-4}$ & $\mathrm{C}_{2-5}$ & $\mathrm{C}_{2-6}$ & $\mathrm{C}_{2-7}$ & $\mathrm{C}_{3-1}$ & $\mathrm{C}_{3-2}$ & $\mathrm{C}_{3-3}$ \\
\hline & Max & Max & Max & Max & Max & Max & Max & Min & Max & Max & Min & Max & Max & Max \\
\hline Weights & 0.062 & 0.106 & 0.090 & 0.076 & 0.070 & 0.081 & 0.057 & 0.057 & 0.048 & 0.057 & 0.040 & 0.105 & 0.081 & 0.070 \\
\hline $\mathrm{A} 1$ & 8.1 & 8.2 & 7.4 & 3.5 & 3.9 & 5.9 & 7.1 & 3.9 & 7.3 & 7.9 & 1.5 & 7.5 & 8.8 & 8.6 \\
\hline $\mathrm{A} 2$ & 8.3 & 5.3 & 6.1 & 6.6 & 3.4 & 3.2 & 2.5 & 8.3 & 4.7 & 2.7 & 6.4 & 7.9 & 2.4 & 3.1 \\
\hline A3 & 2.3 & 6.2 & 2.3 & 3 & 7.4 & 6.5 & 7.5 & 1.2 & 6 & 8.4 & 3.5 & 1.5 & 5.3 & 8.9 \\
\hline A4 & 4.4 & 3.5 & 4.5 & 4.7 & 7.1 & 6.6 & 7.9 & 1.4 & 5.5 & 7.3 & 3.3 & 2.3 & 4.9 & 9 \\
\hline$\sum$ & 23.1 & 23.2 & 20.3 & 17.8 & 21.8 & 22.2 & 25 & 14.8 & 23.5 & 26.3 & 14.7 & 19.2 & 21.4 & 29.6 \\
\hline
\end{tabular}

Table 9. Weighted normalized matrix

\begin{tabular}{|c|c|c|c|c|c|c|c|c|c|c|c|c|c|c|}
\hline \multirow[t]{2}{*}{ Opt } & $\mathrm{C}_{1-1}$ & $\mathrm{C}_{1-2}$ & $\mathrm{C}_{1-3}$ & $\mathrm{C}_{1-4}$ & $\mathrm{C}_{2-1}$ & $\mathrm{C}_{2-2}$ & $\mathrm{C}_{2-3}$ & $\mathrm{C}_{2-4}$ & $\mathrm{C}_{2-5}$ & $\mathrm{C}_{2-6}$ & $\mathrm{C}_{2-7}$ & $\mathrm{C}_{3-1}$ & $\mathrm{C}_{3-2}$ & $\mathrm{C}_{3-3}$ \\
\hline & Max & Max & Max & Max & Max & Max & Max & Min & Max & Max & Min & $\operatorname{Max}$ & Max & Max \\
\hline A1 & 0.0217 & 0.0375 & 0.0326 & 0.0150 & 0.0125 & 0.0215 & 0.0163 & 0.0151 & 0.0148 & 0.0172 & 0.0041 & 0.0409 & 0.0335 & 0.0203 \\
\hline A2 & 0.0222 & 0.0243 & 0.0269 & 0.0284 & 0.0109 & 0.0116 & 0.0057 & 0.0322 & 0.0095 & 0.0059 & 0.0173 & 0.0431 & 0.0091 & 0.0073 \\
\hline A3 & 0.0062 & 0.0284 & 0.0101 & 0.0129 & 0.0237 & 0.0236 & 0.0172 & 0.0047 & 0.0121 & 0.0183 & 0.0095 & 0.0082 & 0.0202 & 0.0210 \\
\hline $\mathrm{A} 4$ & 0.0118 & 0.0160 & 0.0198 & 0.0202 & 0.0227 & 0.0240 & 0.0181 & 0.0054 & 0.0111 & 0.0159 & 0.0089 & 0.0125 & 0.0186 & 0.0212 \\
\hline
\end{tabular}

Table 10. Final results and ranking

\begin{tabular}{lllll}
\hline $\mathrm{P}$ & $\mathrm{R}$ & $\mathrm{Q}$ & $\mathrm{N}$ & Ranking \\
\hline 0.2838 & 0.0192 & 0.2942 & 100 & 1 \\
0.2049 & 0.0495 & 0.2089 & 0.7101 & 4 \\
0.2019 & 0.0141 & 0.2161 & 0.7343 & 3 \\
0.2122 & 0.0144 & 0.2261 & 0.7684 & 2 \\
$\mathrm{R}_{\text {min }}$ & 0.0972 & & & \\
\hline
\end{tabular}

in a nutshell experts decided to consider criteria qualitative because they believe that quantitative criteria didn't important for this research and it can derivate concentrate of experts from strategic and foresight perspective.

\section{SWARA RESULTS}

In this section, SWARA applied for evaluating the model of research that presented in Table 2. Weights and relative importance of each criterion and sum criterion will be calculated in this section. Experts participated in this section at a conference meeting, because they had to make decision together, but each expert presented his/her idea separately. Conference meeting was a good situation and opportunity for experts so that they could consider different perspectives of fields.

\section{COPRAS RESULTS}

COPRAS method was used to evaluate and select alternatives after determining all weights of each criterion and sub-criterion through the SWARA method. At this stage of the application, the group of experts evaluated each alternative according to each criterion and Table 8 was developed. There are many researches with all qualitative criteria without calculating the normalize matrix and that's true.

Besides, Table 8 indicates initial decision making matrix, with the criterion values. The values are based on the average of experts' ideas. For the weight $q_{i}$ of criteria, we used weights in Tables 4 to 7 . As mentioned before, the aim of using SWARA is to determine importance weight of criteria that will be employed in COPRAS method.

The initial decision making matrix has been normalized first, as discussed in previous section. The weighted normalized decision making matrix is presented in Table 9. According to the results of Table 10 which shows evaluation of utility degree, $\mathrm{A}_{1}>\mathrm{A}_{4}>\mathrm{A}_{3}>\mathrm{A}_{2}$.

According to the last column of Table 10, $A_{1}$ is defined as the best alternative for glasshouse locating.

\section{CONCLUSIONS}

In the last decades, importance of locating increased by developing countries, cities, industries and populations. There are many important issues for importance of location of something that include transportation, cost and etc. In the last decade, many MCDM methods applied for locating and this issue illustrates that MCDM methods has high potential to solve locating problems.

This research tries to solve locating problem of glasshouses. Glasshouse, as we mentioned in the 
abstract, is a kind of greenhouse that is larger than prevalent size. Besides, glasshouse is more applicable and has various dimensions. The role of glasshouse in Tehran is considerable and it is a part of the development plan of this metropolis. Glasshouse can satisfy a part of cultural, economical and scientific requirements effectually.

Consequently, two MCDM methods are applied in this research. This hybrid model makes a powerful framework for locating issues. SWARA is applied for evaluating criteria and weighting them. SWARA has the advantage by which decision makers can select their priority at first. They should not accept some limitations of the research. In this research, SWARA played a key role in process of the research. COPRAS is another method of MCDM methods that is used in this research for evaluating and prioritizing alternatives of the research.

Model of this research is established after survey in literature review of this area. The model is includes 3 main criteria are included: Physical condition and potential, Environment and Accessibility.

After searching by experts, four alternatives (places) selected for this research including: Pardisan Park, Bustan-e-Mellat Park, Botanic Garden of University of Tehran and Chitgar Park. Final results demonstrated that Pardisan Park is the best place for establishing a glasshouse in Tehran, Iran.

Authors propose that this methodology can be applied in all around the world. Authors also believe that this methodology can be useful in solving other problems in locating and other issues.

Authors suggest these matters for future researches bellow:

- Applying this methodology in other places and other countries, and comparing the results of that research with this research.

- Applying this methodology with other areas of the research.

- Comparing this methodology with other methodologies that presented before for locating in a review article.

- Sensitivity analysis of experts' ideas in SWARA method.

\section{REFERENCES}

Aghdaie, M. H.; Hashemkhani Zolfani, S.; Zavadskas, E. K. 2013a. Decision making in machine tool selection: an integrated approach with SWARA and COPRAS-G methods, Inzinerine Ekonomika - Engineering Economics 24(1): 5-17.
Aghdaie, M. H.; Hashemkhani Zolfani, S.; Zavadskas, E. K. 2013b. Market segment evaluation and selection based on application of Fuzzy AHP and COPRAS-G methods, Journal of Business Economics and Management 14(1): 213-233. http://dx.doi.or g/10.3846/16111699.2012.721392

Aghdaie, M. H.; Hashemkhani Zolfani, S.; Zavadskas, E. K. 2012. Prioritizing constructing projects of municipalities based on AHP and COPRAS-G: a case study about footbridges in Iran, Baltic Journal of Road and Bridge Engineering 7(2): 145-153. http:// dx.doi.org/10.3846/bjrbe.2012.20

Barysienè, J. 2012. A multi-criteria evaluation of container terminal technologies applying the COPRASG method, Transport 27(4): 364-372. http://dx.doi.or $\mathrm{g} / 10.3846 / 16484142.2012 .750624$

Chandra Das, M.; Sarkar, B.; Ray, S. 2012. A framework to measure relative performance of Indian technical institutions using integrated fuzzy AHP and COPRAS methodology, Socio-Economic Planning Sciences 46(3): 230-241. http://dx.doi.org/10.1016/j. seps.2011.12.001

Chu, C. R.; Chen, R. H.; Chen, J. W. 2011. A laboratory experiment of shear-induced natural ventilation, $E n$ ergy and Buildings 43(10): 2631-2637. http://dx.doi. org/10.1016/j.enbuild.2011.06.014

Church, R. L.; Murray, A. T. 2009. Business site selection, location analysis, and GIS. John Wiley \& Sons.

Daskin, M. S. 1995. Network and discrete location: models, algorithms, and applications. Wiley. http://dx.doi. org/10.1002/9781118032343

De Chiara, J.; Callender, J. H. 1990. Time-saver standards for building types. McGraw-Hill.

Farahani, R. Z.; Steadie Seifi, M.; Asgari, N. 2010. Multiple criteria facility location problems: a survey, Applied Mathematical Modelling 34(7): 1689-1709. http://dx.doi.org/10.1016/j.apm.2009.10.005

Francis, R. L.; McGinnis, L. F.; White, J. A. 1992. Facility layout and location: an analytical approach. Prentice Hall.

Freeman, M. 1998. Greenhouse basics, gardening in your greenhouse. Stackpole Books.

Ginevicius, R. 2011. A new determining method for the criteria weights in multi-criteria evaluation, International Journal of Information Technology \& Decision Making 10(6): 1067-1095. http://dx.doi.org/10.1142/ S0219622011004713

Gudienè, N.; Banaitis, A.; Podvezko, V.; Banaitienè, N. 2014. Identification and evaluation of the critical success factors for construction projects in Lithuania: AHP approach, Journal of Civil Engineering and Management 20(3): 350-359. http://dx.doi.org/1 0.3846/13923730.2014.914082

Guneri, A. F.; Cengiz, M.; Seker, S. 2009. A fuzzy ANP approach to shipyard location selection, Expert Systems with Applications 36(4): 7992-7999. http:// dx.doi.org/10.1016/j.eswa.2008.10.059

Handler, G. Y.; Mirchandani, P. B. 1979. Location on networks: theory and algorithms. MIT Press.

Hasandokht, M. 2005. Greenhouse management (greenhouse product technologies). $1^{\text {st }}$ ed. Marzedanesh publication (In Persian). 
Hashemkhani Zolfani, S.; Chen, I. S.; Rezaeiniya, N.; Tamosaitiene, J. 2012. A Hybrid MCDM model encompassing AHP and COPRAS-G method for the selection of company supplier: a case in Iran, Technological and Economic Development of Economy 18(3): 529-543. http://dx.doi.org/10.3846/20294913.2012.7 09472

Hashemkhani Zolfani, S.; Zavadskas, E. K.; Turskis, Z. 2013a. Design of products with both International and Local perspectives based on Yin-Yang balance theory and SWARA method, Economska IstraživanjaEconomic Research 26(2): 153-166.

Hashemkhani Zolfani, S.; Esfahani, M. H.; Bitarafan, M.; Zavadskas, E. K.; Lale Arefi, S. 2013b. Developing a new hybrid MCDM method for selection of the optimal alternative of mechanical longitudinal ventilation of tunnel pollutants during automobile accidents, Transport 28(1): 89-96. http://dx.doi.org/ 10.3846/16484142.2013.782567

Hashemkhani Zolfani, S.; Farrokhzad, M.; Turskis, Z. 2013c. Investigating on successful factors of online games based on explorer, E a M: Ekonomie a Management 16(2): 161-169.

Hashemkhani Zolfani, S.; Aghdaie, M. H.; Derakhti, A.; Zavadskas, E. K.; Morshed Varzandeh, M. H. 2013d. Decision making on business issues with foresight perspective; an application of new hybrid MCDM model in shopping mall locating, Expert Systems with Applications 40: 7111-7121. http://dx.doi. org/10.1016/j.eswa.2013.06.040

Hashemkhani Zolfani, S.; Zavadskas, E. K. 2013. Sustainable development of rural areas' building structures based on local climate, Procedia Engineering 57: 1295-1301. http://dx.doi.org/10.1016/j.proeng.2013.04.163

Hixon, H. 2009. Growing under glass: your guide to greenhouse gardening success. BookSurge Publishing.

Hooff, T. van; Blocken, B. 2010. On the effect of wind direction and urban surroundings on natural ventilation of a large semi-enclosed stadium, Computers \& Fluids 39(7): 1146-1155. http://dx.doi.org/10.1016/j. compfluid.2010.02.004

Horan, J. M.; Finn, D. P. 2008. Sensitivity of air change rates in a naturally ventilated atrium space subject to variations in external wind speed and direction, Energy and Buildings 40(8): 1577-1585. http:// dx.doi.org/10.1016/j.enbuild.2008.02.013

Jaafarnia, S.; Homaei, M. 2009. Comprehensive and illustrated guide, Greenhouse cultivation of cucumbers and tomatoes. $7^{\text {th }}$ ed. Iran green agriculture school.

Jones, M. P. 1966. A survey of glasshouses and glasshouse practice, Journal of Agricultural Engineering Research 11(2): 113-123. http://dx.doi.org/10.1016/ S0021-8634(66)80047-1

Kersuliene, V.; Turskis, Z. 2011. Integrated fuzzy multiple criteria decision making model for architect selection, Technological and Economic Development of Economy 17(4): 645-666. http://dx.doi.org/10.3846/20 294913.2011.635718

Keršulienė, V.; Zavadskas, E. K.; Turskis, Z. 2010. Selection of rational dispute resolution method by applying new step-wise weight assessment ratio analysis
(SWARA), Journal of Business Economics and Management 11(2): 243-258. http://dx.doi.org/10.3846/ jbem.2010.12

Kronenberg, H. G.; Van de Hulst, H. C. 1984. Stability and instability of production of early glasshouse tomatoes in The Netherlands, Scientia Horticulturae 23(2): 129-136. http://dx.doi.org/10.1016/03044238(84)90016-5

Love, R. F.; Morris, J. G.; Wesolowsky, G. O. 1988. Facilities location: models \& methods. North-Holland.

Marshal, R. 2006. How to build your own greenhouse; design \& plans to meet your growing needs. Versa Press.

Mirchandani, P. B.; Francis, R. L. 1990. Discrete location theory. Wiley.

Mollahoseini, H.; Seylsepur, M. 2008. Greenhouse production management. $1^{\text {th }}$ ed. Sarva publication.

Mulliner, E.; Smallbone, K.; Maliene, V. 2013. An assessment of sustainable housing affordability using a multiple criteria decision making method, Omega 41(2): 270-279. http://dx.doi.org/10.1016/j. omega.2012.05.002

Nguyen, H. T.; Md Dawal, S. Z.; Nukman, Y.; Aoyama, H. 2014. A hybrid approach for fuzzy multiattribute decision making in machine tool selection with consideration of the interactions of attributes, Expert Systems with Applications 41(6): 3078-3090. http://dx.doi.org/10.1016/j.eswa.2013.10.039

Nickel, S.; Puerto, J. 2005. Location theory: a unified approach. Springer.

Nisbet, S. K.; Chee, K. K. 1977. The application of heat pumps to glasshouses, Building and Environment 12(3): 165-174. http://dx.doi.org/10.1016/03601323(77)90014-2

Pellicer, E.; Victory, R. 2006. Implementation of project management principles in Spanish residential developments, International Journal of Strategic Property Management 10(4): 233-248.

Ranjan Maity, S.; Chatterjee, P.; Chakraborty, S. 2012. Cutting tool material selection using grey complex proportional assessment method, Materials \& Design 36: 372-378. http://dx.doi.org/10.1016/j.matdes.2011.11.044

Reason, J. 1990. Human error. Cambridge University Press. http://dx.doi.org/10.1017/CBO9781139062367

Rezaeiniya, N.; Hashemkhani Zolfani, S.; Zavadskas, E. K. 2012. Greenhouse locating based on ANPCOPRAS-G methods - an empirical study based on Iran, International Journal of Strategic Property Management 16(2): 188-200. http://dx.doi.org/10.38 46/1648715X.2012.686459

Rezaeiniya, N.; Safaei Ghadikolaei, A.; Mehri Tekmeh, J.; Rezaeiniya, H. 2014. Fuzzy ANP approach for new application: greenhouse location selection; a case in Iran, Journal of Mathematics and Computer Science 8: 1-20.

Saaty, L. T. 1980. The analytic hierarchy process. New York: McGraw Hill Company.

Saaty, L. T.; Vargas, L. G. 2001. Models, methods, concepts \& applications of the analytical hierarchy process. Boston: Kluwer Academic Publishers. http:// dx.doi.org/10.1007/978-1-4615-1665-1 
Saho, N. K.; Datta, S.; Mahapatra, S. S. 2012. Establishing green supplier appraisement platform using grey concepts, Grey Systems: Theory and Application 2(3): 395-418.

Shannon, C. E. 1948. The mathematical theory of communication, Bell System Technical Journal 27: 379-423. http://dx.doi.org/10.1002/j.1538-7305.1948. tb01338.x

Staniunas, M.; Medineckiene, M.; Zavadskas, E. K.; Kalibatas, D. 2013. To modernize or not: ecological-economical assessment of multi-dwelling houses modernization, Archives of Civil and Mechanical Engineering 13(1): 88-98. http://dx.doi.org/10.1016/j. acme.2012.11.003

Sušinskas, S.; Zavadskas, E. K.; Turskis, Z. 2011. Multiple criteria assessment of pile-columns alternatives, Baltic Journal of Road and Bridge Engineering 6(3): 77-83. http://dx.doi.org/10.3846/bjrbe.2011.19

Sheldrake, R. 1992. Plastic greenhouse manual planning, construction, and operation. Ithaca: Department of Fruit and Vegetable Science, College of Agriculture and Life Sciences, Cornell University.

Tamosaitiene, J.; Gaudutis, E. 2013. Complex assessment of structural systems used for high-rise build- ings, Journal of Civil Engineering and Management 19(2): 305-317. http://dx.doi.org/10.3846/13923730.2 013.772071

Trading Economics. 2013. Available at: http://www. tradingeconomics.com/iran/inflation-cpi

Weber, A.; Friedrich, C. J. 1929. Theory of the location of industries. University of Chicago Press.

Zavadskas, E. K.; Kaklauskas, A. 1996. Determination of an efficient contractor by using the new method of multi criteria assessment, in D. A. Langford, A. Retik (Eds.). International Symposium for "The Organization and Management of Construction". Shaping Theory and Practice. Vol. 2: Managing the Construction Project and Managing Risk, CIB W 65, London, Weinheim, New York, Tokyo, Melbourne, Madras. London: E and FN SPON, 94-104.

Zavadskas, E. K.; Kaklauskas, A.; Sarka, V. 1994. The new method of multicriteria complex proportional assessment of projects, Technological and Economic Development of Economy 1(3): 131-139.

Zhang, Z. Q. 2003. Mites of greenhouses: identification, biology and control. CABI Publishing. http://dx.doi. org/10.1079/9780851995908.0000 